Kajian Jurnalisme

ISSN 2549-0559 (cetak) ISSN 2549-1946 (online)

Volume 02 Nomor 01 Tahun 2018

\title{
Pemaknaan Perempuan Jurnalis Televisi Di Kota Bandung Terhadap Profesi Jurnalis
}

\author{
Anissa Dea Widiarini, Siti Karlinah, Maimon Herawati \\ Program Studi Ilmu Jurnalistik, Fakultas Ilmu Komunikasi Universitas Padjadjaran, \\ E-mail: anissadeawidiarini08@gmail.com
}

\begin{abstract}
This research aims to acknowledge the interpretation of journalists by female tv journalists in Bandung towards their profession. This research applies qualitative method and phenomenology approach on female tv journalists in Bandung. Depth interviews with six female tv journalists, observation, dan literature study are employed to gather the data. The results of the research are analysed utilising qualitative and interpretative analyses. This research has shown that female tv journalists in Bandung recognizes their profession as a challenging and skillfu profession, but also as a profession which help them extending their network in journalist areas. A challenging profession means that the profession is dynamic, full of challenge, and required responsibility. A skillful profession means that the profession requires passion, bravery, and idealism. A profession which could help extending network means that the profession will extend its practioner's relation and knowledge. The meaning of journalists as profession is based on the informants's past experiences (because-motive), the interaction between informants and other people, and how other people precieved their profession as journalists.
\end{abstract}

Key words: bandung city; female journalist; interpretation; phenomenology; television.

\begin{abstract}
Abstrak
Penelitian ini bertujuan untuk mengetahui pemaknaan perempuan jurnalis televisi di Kota Bandung terhadap profesi jurnalis. Penelitian ini menggunakan metode kualitatif dengan pendekatan studi fenomenologi terhadap perempuan jurnalis televisi di Kota Bandung. Teknik pengumpulan data yang digunakan adalah wawancara mendalam, observasi, dan studi kepustakaan. Hasil penelitian dianalisis secara kualitatif dan interpretatif. Hasil penelitian menunjukkan bahwa perempuan jurnalis televisi di Kota Bandung memaknai profesi jurnalis sebagai profesi yang menantang, profesi yang membutuhkan keahlian, dan profesi yang memperluas jaringan. Profesi yang menantang dimaknai sebagai profesi yang dinamis, penuh tantangan, dan menuntut tanggung jawab. Profesi yang membutuhkan keahlian dimaknai sebagai profesi yang membutuhkan passion atau keinginan yang tinggi, membutuhkan keberanian, dan membutuhkan idealisme. Profesi yang memperluas jaringan dimaknai sebagai profesi yang menambah relasi dan menambah ilmu. Makna profesi jurnalis ini berasal dari masa lalu informan (because-motive), interaksi informan dengan orang lain, serta bagaimana orang lain memaknai hal yang sama.
\end{abstract}

Kata kunci: fenomenologi; kota bandung; pemaknaan; perempuan jurnalis; televisi. 
Kajian Jurnalisme

ISSN 2549-0559 (cetak) ISSN 2549-1946 (online)

Volume 02 Nomor 01 Tahun 2018

\section{Pendahuluan}

Perempuan pekerja saat ini bukan merupakan hal yang baru atau tabu. Seiring dengan adanya konsep emansipasi wanita dan perkembangan zaman, para perempuan kini bisa bekerja dan meniti karir mereka hingga ke jenjang yang tinggi. Tak jarang para perempuan ini juga bekerja di sektor-sektor yang identik dengan pekerjaan laki-laki, seperti pekerjaan yang menuntut pekerjanya untuk langsung terjun ke lapangan. Salah satunya adalah profesi jurnalistik.

Haris Sumadiria mendefinisikan jurnalistik sebagai kegiatan menyiapkan, mencari, mengumpulkan, mengolah, menyajikan, dan menyebarkan berita melalui media berkala kepada khalayak seluas-luasnya dengan secepat-cepatnya (Sumadiria, 2005:3). Pelakunya disebut dengan jurnalis atau wartawan. Pada praktiknya di lapangan profesi ini menuntut pelakunya untuk selalu siap sedia 24 jam. Profesi ini juga menuntut jurnalis untuk terjun langsung ke lapangan untuk mencari berita dengan tenggat waktu atau deadline yang sudah ditentukan. Hal ini, membuat profesi jurnalis diidentifikasikan dengan maskulinitas.

Kerja jurnalistik juga identik dengan tekanan, pola kerja yang cukup ketat, jam kerja yang tidak menentu, serta risiko di lapangan ketika peliputan yang cukup tinggi. Jurnalis tidak memiliki jam kerja yang pasti, semua disesuaikan dengan tuntutan di lapangan. Ketika terjadi suatu peristiwa yang membutuhkan jurnalis, maka pada saat itu juga jurnalis harus bekerja. Tidak seperti pekerja kantoran yang memiliki jam kerja pasti setiap harinya.

Berdasarkan data dari Aliansi Jurnalis Independen (AJI), total jurnalis di Indonesia pada 2012 mencapai 14.000 orang di berbagai jenis media dan provinsi. Namun, dari jumlah tersebut hanya sekitar 10 persen saja yang merupakan perempuan jurnalis (Luviana, 2012: 29). Jumlah perempuan yang bekerja sebagai jurnalis sebenarnya terus mengalami peningkatan dari tahun ke tahun. Akan tetapi, mereka kebanyakan tidak bertahan dalam waktu yang lama bekerja sebagai jurnalis. Hal ini yang kemudian menyebabkan banyak dari perempuan jurnalis yang tidak mencapai jenjang karir yang cukup tinggi. Kebanyakan dari mereka hanya sebatas sebagai pekerja di lapangan. Jumlah perempuan yang menjabat sebagai pengambil kebijakan di redaksi menjadi sedikit. Di Indonesia (Luviana, 2012: 39), 94 persen perempuan yang menjadi jurnalis merupakan pekerja lapangan. Dan menjadi jurnalis yang bekerja di lapangan sendiri memiliki tekanan dan risiko yang cukup besar. Contohnya, ketika jurnalis mendapatkan tugas untuk meliput demo, bentrok, atau bahkan ke medan perang. Tugas peliputan di lapangan yang diberikan juga tidak memandang gender, apakah laki-laki atau perempuan.

Meskipun belum menjadi pekerjaan yang diminati perempuan, tidak sedikit juga perempuan yang memilih berprofesi sebagai jurnalis. Media cetak, seperti surat kabar juga masih banyak memiliki perempuan jurnalis. Berdasarkan penelitian Aliansi Jurnalis Indonesia (AJI) pada 2009 (Luviana, 2012:31), perempuan jurnalis yang bekerja di media cetak tercatat dengan jumlah paling besar $(41,80 \%)$ diikuti perempuan jurnalis yang bekerja di media televisi $(25,93 \%)$ kemudian perempuan jurnalis yang bekerja di radio $(23,81 \%)$ dan terakhir perempuan jurnalis di media online $(8,47 \%)$. Namun, seperti yang sudah dijelaskan sebelumnya, rata-rata perempuan jurnalis tersebut merupakan pekerja lapangan.

Pada media elektronik seperti televisi, aktualitas dan kecepatan dalam pelaporan berita menjadi salah satu aspek pertama yang harus dipenuhi. Aspek kecepatan dalam pelaporan ini yang membuat para jurnalis televisi memiliki ritme kerja yang cukup cepat, terutama ketika 
harus melakukan liputan yang disiarkan secara langsung. Meski jam kerja biasanya di tentukan berdasarkan shift atau jadwal kerja yang bergantian dengan kelompok lain, tetapi jurnalis televisi ini tidak memiliki deadline yang teratur setiap harinya. Mereka juga harus bisa siap di luar waktu kerja mereka, jika sewaktu-waktu tenaga mereka dibutuhkan untuk melakukan liputan yang mendesak.

Untuk para perempuan jurnalis yang bekerja di televisi, kebanyakan dari mereka bertugas sebagai reporter yang melaporkan berita secara langsung di depan kamera. Di satu sisi, mereka dituntut untuk bisa melakukan kerja-kerja jurnalis, yaitu mencari, mengumpulkan, mengolah, dan menyiarkan berita. Untuk tugas menyiarkan berita, para perempuan jurnalis televisi ini juga secara tidak langsung dituntut untuk tetap bisa tampil cantik dan baik di depan kamera ketika mereka melaporkan berita. Kebanyakan perempuan jurnalis tersebut dijadikan reporter yang menyampaikan berita di depan kamera.

Menjalani pekerjaan sebagai jurnalis, para perempuan ini pun juga mengalami banyak kendala dan hambatan. Menurut AJI, ada 6 permasalahan mendasar yang dialami perempuan jurnalis akibat dunia jurnalistik yang tidak ramah pada perempuan. Hal ini berdasarkan penelitian AJI pada 2009 mengenai Jejak Perempuan jurnalis di Jakarta, Jogjakarta, Pekanbaru, Medan, dan Bali (Luviana, 2012: 18-19), yaitu: (1) Ketimpangan jumlah perempuan jurnalis dan laki-laki, (2) Adanya kekerasan berbasis gender yang menimpa perempuan jurnalis berkeluarga, (3) Adanya hambatan karir setelah berkeluarga, (4) Beberapa perempuan jurnalis masih mendapat upah yang lebih rendah dibanding dengan rekan laki-laki, (5) Hak menyusui yang menjadi hak pekerja perempuan kadang tidak terpenuhi, (6) Perempuan jurnalis mengalami pelecehan seksual pada saat melakukan peliputan.

Hal tersebut menunjukkan bahwa perempuan jurnalis masih mengalami diskriminasi dan ketimpangan. Padahal seharusnya baik perempuan jurnalis dan laki-laki jurnalis mendapat perlakuan yang sama. Terutama ketika melakukan salah satu kegiatan jurnalistik, yakni peliputan berita di lapangan yang memiliki tekanan dan risiko yang cukup tinggi.

Berdasarkan pemaparan tersebut peneliti mencoba meneliti mengenai bagaimana konstruksi sosial para perempuan jurnalis terhadap profesi mereka sebagai jurnalis. Penelitian ini akan mengupas bagaimana konstruksi sosial perempuan jurnalis di televisi terkait motif mereka dalam memilih jurnalis sebagai profesi mereka, pengalaman mereka ketika bekerja sebagai jurnalis di dalam ruang redaksi dan di luar ruang redaksi, serta bagaimana para perempuan jurnalis ini memaknai profesi mereka sebagai jurnalis.

Perempuan jurnalis yang akan diteliti dalam penelitian ini adalah perempuan jurnalis yang bekerja di televisi nasional yang memiliki kantor biro di Kota Bandung. Kota Bandung sendiri merupakan ibu kota dari Provinsi Jawa Barat yang memiliki jumlah penduduk terbesar di Indonesia. Sebagai pusat pemerintahan Jawa Barat, banyak media televisi yang memiliki kantor biro di Bandung. Kantor biro ini juga memproduksi acara sendiri khusus untuk wilayah Jawa Barat, tidak hanya sebagai kontributor peliputan berita di wilayah Jabar yang hanya mengirimkan berita ke kantor pusat. Hampir semua kantor biro televisi nasional untuk wilayah Jawa Barat berkantor di Bandung. Berdasarkan data dari Pejabat Pengelola Informasi dan 
Kajian Jurnalisme

ISSN 2549-0559 (cetak) ISSN 2549-1946 (online)

Volume 02 Nomor 01 Tahun 2018

Dokumentasi (PPID) Kota Bandung pada 2016, tercatat ada 11 media televisi yang berkegiatan di Kota Bandung. (PPID, 2016)

Kantor biro daerah ini memiliki manajemen kerja tersendiri yang berbeda dengan manajemen kerja di kantor pusat. Jam kerja jurnalis di kantor pusat di Jakarta biasanya menggunakan sistem shift. Satu hari biasanya terdapat tiga shift berbeda yang diisi oleh jurnalis-jurnalisnya. Dalam satu hari itu, setiap jurnalis akan mengisi satu shift. Hal berbeda terjadi di kantor biro. Di kantor biro, biasanya jam kerja para jurnalisnya adalah satu hari penuh. Ada yang menerapkan jadwal seperti jam kantor pada umumnya, ada juga yang menerapkan sistem jaga selama satu hari penuh tergantung kebijakan manajemen redaksinya masingmasing.

Menurut Masayu (2017), Reporter Kompas TV Jabar, "Jam kerja kita di sini 24 jam. Jadi bisa dibilang 1 reporter itu satu hari kerja dan harus stand by seharian. Jadi, kalau harus stand by live Kompas pagi, berarti dari jam 3 pagi kita sudah harus stand by, tapi kalau misalnya di Kompas petang nggak ada apa-apa atau Kompas malam tidak ada apa-apa, ya.. kita bisa pulang. Tapi stand by on call terus."

Ada juga redaksi yang memberlakukan jadwal piket di akhir pekan kepada jurnalisnya. Jadi, bisa saja dalam satu minggu para jurnalis itu harus bekerja selama tujuh hari. "Biasanya kerja tuh 5 hari Senin sampai Jumat. Tapi kalau lagi kebagian piket atau harus stand by ya bisa 7 hari kerjanya. Senin sampai Minggu”, papar Deasy (2017)

Selain itu, rata-rata kantor biro tidak memiliki jurnalis dalam jumlah yang banyak. Hal inilah yang membuat kerja jurnalis di kantor biro berbeda. Jumlah jurnalis yang terbatas tersebut berbanding terbalik dengan wilayah liputan serta tugas mereka sebagai jurnalis. Dengan jumlah jurnalis yang terbatas itu, kantor biro ini harus bisa memenuhi kebutuhan berita untuk siaran lokal mereka dan juga memenuhi kebutuhan berita yang diminta oleh kantor pusat mereka.

Hal tersebut membuat tantangan yang dihadapi jurnalis di Kota Bandung cukup tinggi. Para perempuan jurnalis di televisi tidak hanya bersaing dengan jurnalis televisi lainnya, tapi juga dengan media massa lain seperti radio, media daring, dan surat kabar. Mereka juga harus terbiasa dengan manajemen kerja di kantor biro televisi. Selain itu, media massa di Bandung juga sudah berkembang dengan pesat dan besar dengan persaingan yang besar pula, meskipun belum sebesar media-media massa di Jakarta.

Penelitian ini difokuskan pada bagaimana perempuan jurnalis televisi di Kota Bandung memaknai profesi mereka sebagai jurnalis. Kata makna menurut Kamus Bahasa Indonesia dalam jaringan memiliki arti sebagai pengertian yang diberikan kepada suatu bentuk kebahasaan. Sementara pemaknaan memiliki arti sebagai proses, cara, perbuatan memaknai. Secara sederhana istilah makna yang membentuk kata pemaknaan dapat diartikan sebagai maksud atau esensi akan sesuatu dan bersifat konseptual (Kattsoff, 1996:169). Istilah pemaknaan dapat diterjemahkan sebagai upaya untuk menyematkan (memberikan) maksud atau esensi akan sesuatu yang pada akhirnya akan melahirkan bentuk konsep tersendiri.

Penelitian ini menggali bagaimana pemaknaan yang dimiliki perempuan jurnalis televisi di Kota Bandung terkait profesi mereka sebagai jurnalis yang bekerja di ruang redaksi 
dan di lapangan. Selain itu, peneliti juga hendak mencari tahu bagaimana para perempuan jurnalis ini memaknai perempuan yang berprofesi sebagai jurnalis.

Profesi jurnalis sendiri saat ini sudah jauh berbeda dengan zaman dahulu, di mana saat ini perkembangan teknologi dan komunikasi memiliki peranan yang besar dalam cara kerja jurnalis. Bentuk dari jurnalistik saat ini juga semakin beragam, seiring dengan perkembangan zaman dan teknologi. Jika dahulu jurnalistik diawali dengan bentuk media cetak, kini bentuk jurnalistik sudah beragam seperti jurnalistik radio yang berbasis audio, televisi yang berbasis audiovisual, dan jurnalistik dalam jaringan (daring) yang dapat memuat tulisan, foto, audio, dan video dalam satu wadah.

Perkembangan teknologi komunikasi dan informasi tersebut membuat media juga mengalami perubahan. Perubahan tersebut kemudian mengarah kepada lahirnya media baru. Denis McQuail dalam bukunya Teori Komunikasi Massa (McQuail, 2011:43) menjelaskan bahwa media baru memiliki beberapa ciri utama, yaitu

- Adanya saling keterhubungan.

- Memiliki akses terhadap khalayak yang merupakan penerima maupun pengirim pesan.

- Interaktivitasnya

- Kegunaan yang beragam sebagai karakter yang terbuka.

- Sifatnya yang ada di mana-mana.

Media baru sendiri memiliki perbedaan dengan media lama. Media baru mengabaikan batasan percetakan dan model penyiaran dengan memungkinkan terjadinya percakapan antar banyak pihak, memungkinkan penerimaan secara simultan, perubahan dan penyebaran kembali objek-objek budaya, mengganggu tindakan komunikasi dari pentingnya hubungan kewilayahan dan modernitas, menyediakan kontak global secara instan, dan memasukkan subjek modern/akhir modern ke dalam mesin yang berjaringan, jelas Poster dalam McQuail, (2011:151).

Salah satu bentuk media yang identik dengan media baru adalah internet. Saat ini melalui internet akses terhadap informasi semakin mudah. Bisa dilakukan di mana saja dan kapan saja, tanpa adanya batasan waktu bahkan wilayah. Munculnya media baru ini juga kemudian mempengaruhi media massa. Media massa pun terus berubah seiring dengan perkembangan teknologi komunikasi. Salah satu hal yang bisa terlihat perubahannya adalah platform media massa yang semakin berkembang. Jika dahulu platform media hanya berupa cetak, radio, dan televisi yang terpisah-pisah. Kini semua platform itu dapat digabungkan menjadi satu platform yang bisa mencakup semuanya melalui internet. Lewat sebuah laman di internet, khalayak dapat mengakses berbagai bentuk media massa dalam satu waktu. Disaat yang bersamaan khayalak dapat memperoleh informasi dalam bentuk tulisan, foto, audio, hingga video. Informasi tersebut juga bisa diakses di mana saja dan kapan saja.

Dengan perubahan media massa yang menjadi media multiplatform, cara media dan jurnalis pun juga ikut berubah. Jika dahulu media massa cetak hanya menghasilkan berita dalam bentuk tulisan dan foto, televisi hanya dalam bentuk video, maka sekarang tidak lagi. Satu media tak hanya menghasilkan berita dalam satu platform saja, tetapi semua platform. 
Kajian Jurnalisme

ISSN 2549-0559 (cetak) ISSN 2549-1946 (online)

Volume 02 Nomor 01 Tahun 2018

Media cetak, misalnya, tak hanya memproduksi berita berupa tulisan yang dicetak, tapi saat ini harus memiliki laman di internet yang memuat berita-berita mereka dalam bentuk tulisan, foto, dan video. Sama halnya dengan televisi dan radio.

Hal tersebut tentunya berpengaruh terhadap cara kerja redaksi media dan juga jurnalisnya. Para jurnalis saat ini tidak hanya dituntut untuk bisa menghasilkan berita untuk satu platform saja, tetapi dalam berbagai platform. Contohnya media televisi yang saat ini juga memiliki platform berita berupa laman yang juga berisi berita dalam bentuk tulisan. Maka jurnalis televisi pun diharapkan tidak hanya bisa menghasilkan berita dalam bentuk audiovisual saja tetapi juga bisa menghasilkan berita dalam bentuk tulisan dan foto untuk media online.

Tidak hanya itu, saat ini juga terdapat sistem kerja redaksi yang menggabungkan beberapa redaksi media yang berbeda menjadi satu redaksi terpadu. Contohnya media televisi CNN Indonesia yang saat ini redaksinya, yang tadinya berdiri sendiri seperti Transtv, Trans7, dan CNN Indonesia, bergabung dibawah satu redaksi yang disebut CNN Indonesia. Semua jurnalisnya pun dilebur dibawah satu redaksi. Hal ini membuat cara kerja para jurnalisnya sedikit berubah. Berita yang mereka hasilkan tidak hanya dipakai untuk satu stasiun televisi saja, tetapi juga untuk stasiun televisi lainnya, yang berada di bawah naungan redaksi yang sama. Begitu juga saat jurnalisnya diminta untuk melakukan laporan live dari berbagai tempat. Sangat memungkinkan mereka melakukan beberapa kali laporan live dari berita yang sama, namun untuk stasiun televisi yang berbeda.

Membahas tentang perjalanan perempuan sebagai jurnalis tidak dapat dipisahkan dari ide tentang emansipasi perempuan yang dimulai sejak tahun 1900. R.A. Kartini memperjuangkan kesetaraan antara perempuan dan laki-laki terutama dalam hal pendidikan. Seiring waktu, ide tentang perempuan dan media tumbuh di Indonesia. Diawali dengan munculnya koran Poetri Hindia pada 1908, kemudian belanjut dengan adanya surat kabar khusus, Soenting Melajoe pada 1912, yang dipimpi oleh Roehanna Koeddoes dan Ratna Djuwita. Soenting Melajoe merupakan surat kabar pertama yang dibat khusus perempuan dan mengupas persoalan-persoalan yang dialami perempuan. Setelah itu, karir dan sepak terjang perempuan jurnalis semakin berkembang dari waktu ke waktu. Bahkan banyak tokoh-tokoh perempuan jurnalis Indonesia yang memiliki sepak terjang yang baik dan karya-karya yang hebat (Luviana, 2012: 119-122) .

Dewasa ini, dunia jurnalistik dan media massa sudah sangat berkembang seiring dengan perkembangan teknologi komunikasi. Di tengah era kapitalis media seperti saat ini, peran jurnalis sudah mulai berubah menjadi alat untuk mengumpulkan keuntungan. Aspek kapitalisme ini sudah masuk ke dalam sisi berita. Dimana berita dapat menentukan rating dan keuntungan bagi sebuah perusahaan media. Sebagai bagian dari pekerja media, perempuan jurnalis juga merasakan dampaknya. Setidaknya ada dua dampak, yaitu semakin terbukanya kesempatan bagi perempuan untuk bekerja di media dan setara dengan pekerja laki-laki. Kedua, media saat ini semakin mengarah ke bentuk konvergensi, yang berarti jurnalis dituntut untuk bekerja dalam dua atau lebih bentuk media yang berbeda, menyebabkan tugas yang diterima semakin banyak dan jam kerja yang tidak pasti (Herawati, 2015: 297-305).

Data dari Aliansi Jurnalis Independen (AJI) menyebutkan, total jurnalis di Indonesia pada 2012 mencapai 14.000 orang di berbagai jenis media dan provinsi. Namun, jumlah 
perempuan jurnalis di Indonesia masih jauh dibandingkan jurnalis laki-laki, dari jumlah tersebut hanya sekitar 10 persen saja yang merupakan perempuan jurnalis, atau hanya sekitar 1:3 atau 1:4 di Indonesia (Luviana, 2012: 27-29).

Jumlah perempuan yang bekerja sebagai jurnalis sebenarnya terus mengalami peningkatan dari tahun ke tahun. Data dari AJI pada 2012 menunjukkan bahwa persentase jumlah perempuan jurnalis di Indonesia sebesar 18,6\% . Hal ini menunjukkan meski mengalami peningkatan, tetapi jumlah perempuan yang bekerja sebagai jurnalis masih cukup rendah. Selain itu, kebanyakan dari mereka tidak bertahan dalam waktu yang lama bekerja sebagai jurnalis. Hal ini yang kemudian menyebabkan banyak dari perempuan jurnalis yang tidak mencapai jenjang karir yang cukup tinggi. Kebanyakan dari mereka hanya sebatas sebagai pekerja di lapangan. Jumlah perempuan yang menjabat sebagai pengambil kebijakan di redaksi menjadi sedikit. Di Indonesia (Luviana, 2012: 39), 94 persen perempuan yang menjadi jurnalis merupakan pekerja lapangan.

Istilah yang menjelaskan mengenai masih sedikitnya perempuan yang mencapai jenjang karir tertinggi dalam pekerjaannya adalah "The Glass Ceiling”. Istilah ini pertama kali digunakan pada pertengahan tahun 1980 di Amerika untuk menjelaskan tentang tembok pembatas kasat mata yang menghalangi perempuan dari promosi kenaikan jabatan menuju jabatan yang lebih tinggi. Biasanya hal ini terjadi di dunia bisnis, namun yang menarik adalah istilah ini awalnya digunakan dalam artikel tentang jurnalis. Meski dalam hal ini terdapat juga perempuan jurnalis yang mencapai peran tertinggi dalam dunia jurnalistik, tetapi jumlahnya masih terbilang rendah bahkan cenderung sedikit. Hal ini menunjukan bahwa "glass ceiling" ini masih belum bisa dihancurkan, meski begitu perubahan ke arah yang lebih baik masih terus terjadi (Pate, 2014: 103-105).

"The phrase glass ceiling was first used in 1984 in an Adweek profile of Gay Bryant, who at the time was the editor of Working Woman magazine. In that profile, she was quoted as saying, "Women have reached a certain point - I call it the glass ceiling ... in the top of middle management and they're stopping and getting stuck" (Boyd, 2012; Pate, 2014: 103)

Keberadaan perempuan sebagai pekerja media sendiri sebenarnya sangat penting. Kehadiran pekerja perempuan ini dapat menyeimbangkan sudut pandang yang ditampilkan oleh media, tidak hanya pandangan dari pihak laki-laki saja. Kurang atau bahkan tidak adanya pekerja perempuan di media akan mengurangi sudut pandang dan pemahaman tentang perempuan. Tidak hanya akan mempengaruhi pandangan khalayak terhadap perempuan, tetapi juga akan mempengaruhi kebijakan publik yang berkaitan dengan perempuan (Herawati, 2016).

Pelatihan-pelatihan yang terkait dengan jurnalistik menjadi suatu hal yang cukup penting. Selain meningkatkan keahlian dan kemampuan jurnalis dalam mencari berita, pelatihan juga dapat meningkatkan kepekaan jurnalis terhadap isu-isu di sekitarnya. Berdasarkan data AJI (Luviana, 2012: 38), perempuan jurnalis yang pernah mengikuti pelatihan jurnalistik dengan perspektif gender masih rendah jumlahnya. Hasilnya total $82,56 \%$ 
Kajian Jurnalisme

ISSN 2549-0559 (cetak) ISSN 2549-1946 (online)

Volume 02 Nomor 01 Tahun 2018

belum pernah mendapatkan pelatihan. Pelatihan berperspektif gender ini menjadi penting karena dapat terlihat sejauh mana keberpihakan perempuan jurnalis pada isu-isu perempuan dan juga kepedulian dari media tempat mereka bekerja tentang isu perempuan dan perempuan jurnalis.

Untuk pelatihan dan pendidikan tambahan, baik formal dan informal, menurut AJI, media saat ini sudah banyak menyediakannya dan membuka kesempatan seluas-luasnya, termasuk kepada perempuan jurnalis. Media di Indonesia kini tidak membedakan kesempatan untuk memperoleh pendidikan berdasarkan gender. Perempuan jurnalis memperoleh kesempatan yang sama, seperti rekan kerja laki-lakinya, yang membedakan adalah kemampuan masing-masing jurnalis untuk mengembangkan diri setelah mendapatkan ilmu-ilmu baru (Luviana, 2012: 69-70).

Keberadaan perempuan jurnalis di Indonesia sudah diakui, jumlahnya juga semakin meningkat, dan kesempatan belajar yang juga semakin meningkat. Akan tetapi, tidak dapat dipungkiri bahwa para perempuan jurnalis ini juga masih banyak menemui kesulitan dalam menjalankan profesinya ini. Masih banyak hak-hak perempuan jurnalis yang belum terpenuhi secara maksimal.

Penelitian AJI (Luviana, 2012: 45) menunjukkan hingga hari ini perempuan jurnalis masih belum banyak yang memahami dan menerima hak-haknya sebagai perempuan pekerja. Contohnya, jatah cuti haid bulanan yang masih belum populer, bahkan di kalangan perempuan jurnalis. Para perempuan jurnalis yang sedang menyusui juga belum diberikan waktu khusus untuk menyusui. Meskipun tidak ada perbedaan yang signifikan dalam hal gaji, tetap saja gaji yang diberikan setiap bulannya masih di bawah standar Upah Layak Jurnalis. Selain itu, sebanyak 51,8\% perempuan jurnalis belum mendapatkan fasilitas ketika melakukan peliputan di malam hari.

Teori yang digunakan dalam penelitian ini adalah Teori konstruksi sosial terhadap realitas Berger dan Luckmann dijelaskan dalam buku mereka yang berjudul The Social Construction of Reality. Menurut mereka, seseorang hidup dalam kehidupannya mengembangkan suatu perilaku yang repetitif, yang mereka sebut sebagai kebiasaan. Kebiasaan ini memungkinkan seseorang mengatasi sesuau secara otomatis. Dengan terjadinya interaksi dan komunikasi dengan orang-orang lain, seiring dengan berjalannya waktu beberapa kebiasaan tersebut dapat menjadi milik bersama sebuah masyarakat yang kemudian dapat terbentuk sebuah lembaga (Kuswarno, 2009: 112).

\section{Metode}

Penelitian ini menggunakan penelitian kualitatif. Metode penelitian kualitatif adalah metode penelitian yang berlandaskan pada filsafat konstruktivisme, digunakan untuk meneliti pada kondisi objek yang alamiah, di mana peneliti adalah sebagai instrumen kunci, teknik pengumpulan data dilakukan secara triangulasi (gabungan), analisis data bersifat induktif/kualitatif, dan hasil penelitian kualitatif lebih menekankan makna dari pada generalisasi (Sugiyono, 2012:9). 
Sementara pendekatan yang digunakan adalah pendekatan fenomenologi yang merupakan studi tentang pengalaman dari perspektif orang pertama atau pengalaman individu dalam memahami pengetahuan dan motivasi terkait profesinya.

Penelitian ini menggunakan teknik pengumpulan data dengan wawancara mendalam dengan perempuan jurnalis televisi sebagai teknik pengumpulan data utama. Sementara teknik observasi dan studi literatur digunakan sebagai teknik pengumpulan data pendukung. Melalui pengumpulan data ini akan digali pemaknaan perempuan jurnalis terkait profesinya sebagai jurnalis dan bagaimana pemaknaan mereka terkait perempuan yang berprofesi sebagai jurnalis.

Informan dalam penelitian ini dipilih menggunakan teknik pemilihan sampel bertujuan khusus (purposive sampling). Purposive sampling menurut Sugiyono (2012:119) adalah pengambilan sampel sumber data dengan pertimbangan tertentu. Pertimbangan tertentu ini memberikan kesempatan bagi peneliti untuk memilih informan yang dianggap bisa memberikan dan paling tahu akan informasi yang diharapkan peneliti. Kriteria informan yang ditetapkan dalam penelitian ini adalah perempuan jurnalis televisi di Kota Bandung dan telah bekerja sebagai jurnalis selama minimal satu tahun. Berdasarkan kriteria tersebut, maka terpilih 6 orang informan yang berasal dari televisi lokal maupun biro di Kota Bandung.

\section{Hasil Dan Pembahasan}

Para perempuan jurnalis televisi yang menjadi informan dalam penelitian ini memiliki pemaknaan tersendiri mengenai profesi jurnalis yang mereka geluti. Para informan memaknai profesi jurnalis sebagai profesi yang memiliki makna berdasarkan pekerjaan dan kegiatan yang mereka lakukan. Hasil dari pemaknaan tersebut akan menjadi pertimbangan dan pembentuk tindakan mereka di masa depan.

Interaksi simbolik berasumsi bahwa manusia dapat mengerti berbagai hal dengan belajar dari pengalaman. Persepsi seseorang selalu diterjemahkan dalam simbol-simbol. Sebuah makna dipelajari melalui interaksi di antara orang-orang dan makna tersebut muncul karena adanya pertukaran simbol-simbol dalam kelompok sosial. Selain itu, secara sosial seseorang dapat melakukan tindakan kepada dirinya sendiri, seperti yang dilakukannya kepada orang lain. Dengan kata lain seseorang dapat menjadikan dirinya sendiri sebagai objek dari tindakannya sendiri. Diri (the self) terbentuk dengan cara yang sama sebagai objek melalui definisi yang diciptakan bersama orang lain (Kuswarno, 2009:114).

Konsep diri yang dimiliki seseorang ini menjadi penting dalam pembentukan perilaku. Karena manusia secara aktif membentuk perilaku dirinya sendiri. Sementara tingkah laku atau perilaku seseorang tidak hanya dipengaruhi oleh masa lalunya saja, tetapi juga dengan melalui interaksi dengan dirinya sendiri dan dengan orang lain dalam kelompok sosialnya.

Untuk memahami tindakan yang dilakukan oleh para informan tidak bisa hanya dilakukan dari satu sisi saja, tetapi harus secara menyeluruh. Hal ini karena setiap tindakan yang dilakukan oleh individu memiliki unsur ke masa depan dan juga unsur ke masa lalu. Munculnya tindakan ini dapat digambarkan melalui dua fase, yaitu fase in-order-to motive atau masa yang akan datang dan juga fase because motive atau masa lalu. 
Kajian Jurnalisme

ISSN 2549-0559 (cetak) ISSN 2549-1946 (online)

Volume 02 Nomor 01 Tahun 2018

Berdasarkan hasil penelitian, diketahui para informan dalam penelitian ini memiliki makna tersendiri dalam memandang profesi jurnalis. Meskipun masing-masing informan memiliki makna tersendiri, namun makna yang dimiliki kelimanya tidak jauh berbeda antara satu dengan lainnya. Pengalaman yang dimiliki oleh para informan ini menjadi modal bagi mereka untuk memahami dirinya sendiri, memahami profesi jurnalis yang dijalaninya, dan memahami dirinya sebagai perempuan yang berprofesi sebagai jurnalis.

Para informan memaknai profesi jurnalis sebagai profesi yang memiliki makna, yakni sebagai profesi yang dinamis, penuh tantangan, menuntut tanggung jawab, membutuhkan passion atau keinginan yang tinggi, menambah ilmu, menambah relasi, dan membutuhkan keberanian. Kedelapan makna tersebut dibagi menjadi tiga kategori, yakni (1) profesi yang menantang, (2) profesi yang membutuhkan keahlian, dan (3) profesi yang memperluas jaringan.

Profesi jurnalis sebagai profesi yang menantang diartikan sebagai profesi yang dalam melakukan kegiatannya dibutuhkan usaha untuk menanggulangi masalah yang ada. Dalam menjalankan profesi jurnalis, para informan memiliki makna yang berbeda-beda soal profesi jurnalis, yakni (1) profesi yang dinamis, (2) profesi yang penuh tantangan, dan (3) profesi yang menuntut tanggung jawab.

Makna profesi jurnalis sebagai profesi yang menantang yang pertama adalah profesi yang dinamis. Makna ini diungkapkan oleh Masayu dan Dinda. Masayu (2017) memandang profesi jurnalis sebagai sesuatu yang dinamis karena baginya dalam menjalankan profesi jurnalis, Ia tidak bisa memprediksi secara pasti apa yang akan dikerjakan serta apa yang akan terjadi pada dirinya di hari itu. Setiap harinya akan selalu ada hal-hal yang berbeda yang terjadi.

"Profesi yang dinamis. Pekerjaan yang nggak bisa ditanya apa yang akan dikerjakan hari ini dan apa yang akan diraih hari ini tuh nggak akan tahu. Semuanya itu beyond expectation bangetlah. Jadi, menurut aku kalau ditanya jurnalis itu apa, itu adalah profesi yang dinamis, profesi yang penuh dengan tantangan. Tantangannya mulai dari kecepatan waktu dan kecepatan kemampuan berpikir dan mentalitas sih menurut aku. Baik fisik dan psikis. Soalnya nggak kebayang kalau misalnya kebiasaan dikantor yang dimeja dan diem aja. Sedangkan kita wartawan yang terjun ke lapangan, yang terjun ke banjir dan segalam macam”, ungkap Masayu (2017).

Pekerjaan yang tidak bisa diduga serta pengalaman Masayu dalam melakukan tugasnya inilah yang kemudian membentuk pemaknaan Masayu bahwa profesi jurnalis merupakan profesi yang dinamis. Because-motive Masayu adalah bekerja sebagai jurnalis di Kompas Tv Jabar dengan kegiatan yang berbeda-beda setiap harinya.

Senada dengan Masayu, Dinda juga memaknai profesi jurnalis sebagai profesi yang dinamis. Dinda memaknai profesi jurnalis sebagai profesi yang dinamis karena bagi Dinda apa yang dikerjakan oleh jurnalis setiap harinya sangat fleksibel dengan kegiatan berbeda-beda. Setiap liputannya akan ada hal-hal baru yang terjadi dan dia lakukan. Pekerjaan yang tidak statis dan pengalaman Dinda di lapangan selama berprofes sebagai jurnalis inilah yang membentuk pemaknaan Dinda terhadap profesinya. Hal ini dijelaskan Schutz sebagai becausemotive atau motif masa lalu. 
Makna profesi jurnalis sebagai profesi yang menantang yang kedua adalah profesi yang penuh tantangan. Makna ini dimiliki oleh Masayu dan Deasy. Masayu merupakan jurnalis di Kompas Tv Jabar, sedangkan Deasy merupakan jurnalis di NET Jabar. Dari segi latar belakang pendidikan keduanya bukan lulusan jurnalistik. Masayu merupakan sarjana Ekonomi dan Deasy merupakan sarjana komunikasi, jurusan hubungan masyarakat. Sebelum bekerja, Masayu tidak pernah bersentuhan dengan dunia media dan jurnalistik. Sementara Deasy, sejak kuliah aktif berkegiatan di media sebagai penyiar dan presenter.

Makna yang diberikan keduanya, yakni profesi jurnalis sebagai profesi yang penuh tantangan diperoleh berdasarkan pengalaman mereka. Keduanya masih bertugas sebagai reporter yang melakukan liputan berita di lapangan. Sebagai jurnalis, Masayu mendapatkan penugasan yang sangat beragam dari kantornya. Tidak hanya tugas untuk meliput soal pemerintahan, tetapi juga soal bencana alam dan hal-hal lainnya. Masayu sering ditugaskan untuk meliput peristiwa-peristiwa yang tidak terduga. Selain itu, Masayu menganggap tantangan dalam profesi jurnalis adalah tuntutan kecepatan, keakuratan data, dan kemampuan berpikir jurnalis, baik secara fisik maupun psikis. Baginya, hal tersebut menjadi tantangan tersendiri karena berita yang dihasilkannya tidak hanya harus cepat tetapi juga harus akurat. Hal-hal tersebutlah yang membuat Masayu merasa bahwa profesi jurnalis merupakan profesi yang penuh tantangan. Ini dijelaskan Schutz sebagai because-motive yang mempengaruhi pemaknaan Masayu.

"Seru, banyak tantangan. Terutama buat aku yang orangnya nggak bisa diem. Jadi seneng banget jalan-jalan ke mana gitu. Kalau hitungan diem di kantor sih bisa kehitung, seminggu bisa sehari atau dua hari doang, sisanya di luar. Karena aku suka tantangan, seru, bisa ketemu banyak orang. Intinya lebih ke situ sih”, ungkap Deasy (2017)

Serupa dengan Masayu, Deasy juga merasa bahwa profesi jurnalis merupakan profesi yang penuh dengan tantangan. Deasy memandang profesi jurnalis yang membuatnya banyak bepergian ke tempat-tempat berbeda serta bertemu dengan banyak orang adalah tantangan tersendiri bagi dirinya. Because-motive Deasy adalah ketika dia berkesempatan untuk mengunjungi tempat-tempat baru ketika bertugas sebagai jurnalis.

Masayu dan Deasy sama-sama tidak memiliki latar belakang pendidikan jurnalistik. Pengalaman jurnalistik mereka dapatkan ketika bekerja di televisi. Masa lalu serta pengalaman mereka selama menjalani profesi jurnalistiklah yang menjadi dasar bagi keduanya dalam memaknai profesi jurnalis sebagai profesi yang penuh tantangan.

Makna profesi jurnalis sebagai profesi yang menantang yang ketiga adalah profesi yang menuntut tanggung jawab. Informan yang memiliki makna ini adalah Dian, Liza, dan Revita. Ketiganya sama-sama memaknai profesi jurnalis sebagai profesi yang menuntut tanggung jawab berdasarkan masa lalu dan pengalaman mereka dalam menjalani profesi jurnalis.

"Soalnya tanggung jawabnya bukan cuma ke kantor atau atasan. Tapi juga tanggung jawab ke masyarakat atau penonton. Bahkan tanggung jawab juga ke narasumber kita. Tanggung jawabnya adalah kita jangan sampai salah ngasih informasi. Nggak cuma harus buat berita yang bagus tapi juga harus benar. Gimana caranya supaya berita yang kita bikin itu baik, bagus, dan benar", ungkap Dian (2017). 
Kajian Jurnalisme

ISSN 2549-0559 (cetak) ISSN 2549-1946 (online)

Volume 02 Nomor 01 Tahun 2018

Bagi Dian, tanggung jawab seorang jurnalis adalah untuk memberikan informasi yang benar kepada masyarakat. Tanggung jawab seorang jurnalis ada pada masyarakat sebagai pihak yang menonton berita yang dia hasilkan. Selain itu menurut Dian, dia juga bertanggung jawab kepada atasannya serta narasumber beritanya. Jangan sampai berita yang dia buat memuat informasi yang salah. Because-motive Dian adalah ketika dia menjadi jurnalis dan beritanya disaksikan oleh masyarakat.

"Memberikan informasi yang benar dan jangan sampai menyesatkan orang. Karena kita tuh tugasnya untuk menginterpretasi informasi yang kita dapatkan untuk disebarkan ke banyak orang. Tapi jangan sampai salah, jangan sampai meleset informasinya. Jangan sampai informasinya simpang siur", ungkap Liza (2017).

Liza juga memiliki makna yang serupa. Menurut Liza profesi jurnalis memiliki tanggung jawab untuk memberikan informasi yang benar kepada masyarakat. Selain jurnalis harus memastikan informasi yang disampaikan benar, informasi yang diberikan juga harus bisa mencerdaskan masyarakat. Seperti ketika harus memberitakan tentang peristiwa bom. Di satu sisi informasi mengenai bom banyak beredar luas di media, tapi semua informasi itu masih simpang siur dan belum terbukti kebenarannya. Di situlah jurnalis harus bisa memberikan informasi yang benar bagi masyarakat dan tidak membuat kepanikan. Bagi Liza, inilah yang membuat dirinya merasa bahwa profesi jurnalis merupakan profesi yang menuntut tanggung jawab. Hal ini dijelaskan sebagai because-motive atau motif sebab.

"Jurnalis itu pekerjaan yang tanggung jawabnya besar. Lo bisa merubah berita. Meskipun faktanya benar, tapi cara kita menyampaikan, angle-nya, itu bisa merubah sudut pandang orang lain. Jadi kaya menurutku jurnalis bisa menciptakan perang dunia dengan beritanya", ungkap Revita (2017)

Serupa dengan keduanya, Revita juga memaknai jurnalis sebagai profesi yang menuntut tanggung jawab. Bekerja sebagai jurnalis membuat dia memahami bahwa jurnalis memiliki kekuatan untuk mengatur informasi yang cukup besar. Revita menyadari bahwa jurnalis memiliki kemampuan untuk menggiring cara pandang khalayak terhadap suatu peristiwa hanya dari berita yang dia hasilkan. Masa lalu Revita inilah yang membuat dirinya memaknai profesi jurnalis sebagai profesi yang menuntut tanggung jawab. Ini dijelaskan Schutz sebagai motif sebab atau because-motive.

Profesi jurnalis sebagai profesi yang membutuhkan keahlian diartikan sebagai profesi yang membutuhkan keahlian atau kemahiran khusus untuk menyelesaikan tugas-tugasnya. Pemaknaan yang termasuk dalam kategori ini adalah makna profesi jurnalis yang berhubungan dengan keterampilan. Jurnalis sebagai profesi yang membutuhkan keahlian dimaknai sebagai profesi yang (1) membutuhkan passion atau keinginan yang tinggi, (2) membutuhkan keberanian, dan (3) membutuhkan idealisme.

Makna yang pertama adalah profesi yang membutuhkan keberanian. Makna ini dimiliki oleh Dian. Dian sendiri tidak memiliki latar belakang pendidikan jurnalistik. Makna profesi jurnalis sebagai profesi yang membutuhkan keberanian didapatkan Dian berdasarkan pengalamannya bekerja di lapangan. Pengalamannya bekerja di lapangan membuat Dian harus liputan ke berbagai tempat yang tidak selalu nyaman dan tidak bisa ditebak bagaimana kondisinya. Maka dari itu keberanian dibutuhkan untuk menjalankan tugas-tugas sebagai 
jurnalis. Ini dijelaskan Schutz sebagai motif sebab atau because-motive. Masa lalu Dian melakukan kerja jurnalistik dilapangan yang membuat Dian memiliki pemaknaan bahwa untuk menjalani profesi jurnalistik dibutuhkan keberanian.

Makna profesi jurnalis sebagai profesi yang membutuhkan keahlian yang kedua adalah profesi yang membutuhkan passion atau keinginan yang tinggi. Makna profesi jurnalis ini dimiliki oleh Masayu dan Liza. Masayu dan Liza memiliki latar belakang pendidikan yang berbeda. Liza memiliki latar pendidikan jurnalistik, sementara Masayu memiliki latar pendidikan ekonomi dan tidak pernah mengikuti pelatihan atau kelas yang berhubungan dengan dunia jurnalistik sebelum bekerja.

"Menurut aku passion itu penting sih. Kan ketika kita mencintai sesuatu dan besoknya kita mau ngelakuin itu lagi, kalau nggak punya passion kayanya nggak mau deh. Apalagi perempuan, nggak mau panas, nggak mau item, nggak mau luka, pasti susah banget. Apalagi pekerjaan kita seperti ini”, ungkap Masayu (2017)

Ketika menjadi jurnalis yang meliput di lapangan, Masayu banyak mengalami liputan ke tempat-tempat yang tidak terduga. Selain itu, sebagai orang yang bekerja di lapangan Masayu harus siap bekerja di luar ruangan, di bawah terik matahari, di lokasi bencana, dan juga risiko untuk terluka. Menjadi jurnalis dengan melakukan berbagai tugas di lapangan yang tidak terduga membuat Masayu harus siap menerima risikonya. Jika dirinya tidak memiliki passion di dunia jurnalis ini, dirinya mungkin tidak akan mau melakukan hal-hal tersebut. Baginya passion atau keinginan yang kuat inilah yang menjadi faktor dirinya bisa menjalani profesinya sebagai jurnalis.

Untuk itu, berdasarkan keterangan Masayu makna profesi jurnalis sebagai profesi yang membutuhkan passion atau keinginan yang tinggi di dapat Masayu setelah bekerja di Kompas TV Jabar dan berdasarkan pengalamannya dalam menjalankan profesi jurnalis. Ini dijelaskan sebagai motif sebab.

"Makanya itu harus niat banget, pengen banget, dan suka banget. Kalau nggak suka, habis itu bosen, pasti nantinya mundur. Banyak banget yang kaya gitu. Dan juga butuh dedikasi. Niat lah intinya. Dan jangan baper kalo di eval atau dapet perlakuan kurang enak dari narsum", papar Liza (2017)

Liza juga memberikan makna yang sama seperti Masayu, yakni profesi jurnalis merupakan profesi yang membutuhkan passion atau keinginan yang tinggi. Sama seperti Masayu, keinginan yang tinggi inilah yang membuat Liza tetap bisa menjalankan profesi jurnalis setiap harinya. Liza sendiri tergolong reporter baru di NET Jabar. Berdasarkan pengalaman Liza, profesi jurnalis merupakan profesi yang memiliki ritme kerja yang tidak jauh berbeda setiap harinya. Setiap hari, sejak dia mulai bekerja sebagai jurnalis, kegiatannya diisi dengan liputan dan membuat naskah. Ritme kerja serta kegiatan yang berulang inilah yang, menurut Liza, memungkinkan jurnalis untuk merasa bosan. Selain itu, menurut Liza, jurnalis juga memiliki jam kerja yang tidak jelas dan teratur. Singkatnya, hal tersebutlah yang membuat Liza merasa bahwa profesi yang dia lakukan saat ini membutuhkan passion dari yang menjalankannya. Ini dijelaskan Schutz sebagai motif sebab. Masa lalu Liza melakukan kerja jurnalistik dengan kegiatan yang hampir sama setiap harinya membuat Ia memiliki pemaknaan bahwa profesi 
92 | Kajian Jurnalisme

ISSN 2549-0559 (cetak) ISSN 2549-1946 (online)

Volume 02 Nomor 01 Tahun 2018

jurnalis adalah profesi yang membutuhkan passion atau keinginan yang tinggi dari orang yang menjalaninya.

Makna profesi jurnalis sebagai profesi yang membutuhkan keahlian yang ketiga adalah profesi yang membutuhkan idealisme.

"Karena begitu powerfull-nya jurnalis menguasai informasi. Banyak hal-hal kotor yang ditawarkan ke jurnalis. Kalau nggak ada idealisme ya diambil aja tuh yang kotor-kotor itu. Yang bikin kita jadi tajir bukan main. Jadi memang menurut aku profesi jurnalis adalah profesi yang harus punya idealisme yang tinggi. Harus tahan godaan yang anehaneh", ujar Revita (2017).

Informan yang memiliki makna ini adalah Revita. Ia tidak asing dengan kegiatan jurnalistik karena Ia memiliki latar belakang pendidikan jurnalistik. Sejak kuliah, Revita sudah memiliki pengalaman jurnalistik di lapangan dengan melakukan magang di sebuah media cetak. Revita sendiri telah menjadi jurnalis selama empat tahun. Ia melihat bahwa pekerjaan sebagai jurnalis memiliki risiko serta godaan yang besar. Jurnalis juga memiliki kekuatan untuk mengatur informasi. Sebelum bekerja di televisi, Revita sempat bekerja di tiga media cetak yang berbeda. Makna yang dimiliki Revita semakin kuat karena Ia memiliki pengalaman bekerja di empat media yang berbeda. Ini dijelaskan Schutz sebagai motif masa lalu. Pengalaman bekerja di lapangan yang cukup banyak itu membuat Revita memaknai bahwa profesi jurnalis merupakan profesi yang membutuhkan idealisme.

Kategori makna yang terakhir adalah profesi jurnalis sebagai profesi yang memperluas jaringan. Profesi jurnalis sebagai profesi yang memperluas jaringan diartikan sebagai profesi yang dapat memberikan seseorang yang menjalaninya kesempatan untuk memperluas dan menambah relasi dan ilmu pengetahuan baru. Pemaknaan yang termasuk dalam kategori ini adalah pemaknaan yang berkaitan dengan kelebihan apa saja yang didapat jurnalis selama menjalani profesinya. Jurnalis sebagai profesi yang memperluas jaringan dimaknai sebagai profesi yang (1) menambah relasi, dan (2) menambah ilmu.

Makna profesi jurnalis sebagai profesi yang memperluas jaringan yang pertama adalah profesi yang menambah relasi. Empat informan dalam penelitian ini memaknai profesi jurnalistik sebagai profesi yang menambah relasi. Empat informan tersebut adalah Masayu, Liza, Dian, dan Deasy. Para informan menganggap bahwa kesempatan untuk bertemu dengan banyak orang sebagai jurnalis membuat relasi yang mereka miliki juga semakin luas dan bertambah. Seperti Masayu, dengan pengalamannya sebagai jurnalis Ia banyak bertemu dengan orang-orang baru, mulai dari masyarakat biasa, pejabat, hingga orang-orang yang tidak Ia bayangkan dapat ditemuinya. Because-motive keempat informan ini adalah ketika mereka banyak bertemu orang baru dan memperluas relasi mereka.

Makna profesi jurnalis sebagai profesi yang memperluas jaringan yang kedua adalah profesi yang menambah ilmu. Makna ini dimiliki oleh Liza, Dian, dan Dinda. Liza sendiri memiliki latar belakang pendidikan jurnalistik. Dian tidak memiliki latar pendidikan jurnalistik dan merupakan lulusan S1 hubungan masyarakat. Dinda juga tidak berkuliah di jurusan jurnalistik.

"Jadi tahu banyak lah, banyak belajar. Liputan ekonomi kita jadi belajar ekonomi.

Liputan kriminal jadi hafal pasal-pasal. Liputan kesenian kita jadi tahu kalau ada 
kesenian itu. Banyak tahu, banyak kenalan, banyak informasi, banyak belajar dari orang lain. Termasuk dari wartawan lain”, tutur Liza (2017)

Liza yang memiliki latar belakang pendidikan jurnalistik merasa bahwa profesi jurnalis yang dijalaninya tidak hanya memberikan informasi pada masyarakat, tetapi juga untuk dirinya. Berprofesi sebagai jurnalis televisi membuat Liza melakukan berbagai liputan di berbagai tempat. Topik serta isu yang diliputnya pun beragam, tidak hanya topik-topik tertentu. Meliput berbagai isu dan mewawancarai narasumber dengan latar keahlian yang berbeda-beda membuat Liza belajar tentang berbagai hal juga.

Pemaknaan Liza terhadap profesi jurnalis sebagai profesi yang menambah ilmu telah muncul sejak dirinya masih berkuliah di jurusan jurnalistik dan belum berprofesi sebagai jurnalis. Makna profesi jurnalis sebagai profesi yang menambah ilmu juga diperkuat dengan berbagai ilmu baru di luar latar belakang pendidikannya yang Ia peroleh selama menjadi jurnalis televisi. Liza mengatakan selama menjadi jurnalis Ia memiliki kesempatan untuk belajar tentang ekonomi, hukum, politik, dan sebagainya, yang belum pernah Ia pelajari sebelumnya. Pengalaman Liza di masa lalu sebagai mahasiswa jurnalistik, melakukan liputan dengan berbagai topik berbeda, melakukan wawancara dengan narasumber yang memiliki keahlian yang berbeda membuat Liza merasa profesi jurnalis merupakan profesi yang menambah ilmu. Hal ini dijelaskan Schutz sebagai motif sebab.

Dian juga mengungkapkan hal yang senada dengan Liza. Meskipun tidak memiliki latar belakang pendidikan jurnalistik, pengalamannya melakukan berbagai kegiatan jurnalistik, melakukan peliputan dengan topik serta isu-isu yang berbeda membuat Dian memaknai profesi jurnalis sebagai profesi yang menambah ilmu. Hal ini disebabkan oleh kesempatan yang dimiliki Dian untuk meliput berbagai hal membuat dirinya bisa belajar banyak hal-hal baru yang memperluas serta menambah pengetahuan yang dimilikinya. Because-motive Dian adalah ketika menjadi jurnalis Ia dapat mempelajari hal-hal baru.

"Setiap harinya liputan itu ada pelajaran baru. Kaya hari ini liputan ke Arcamanik dapet pelajaran baru, besok ke Garut dapet pelajaran baru lagi. Jadi setiap hari itu belajar. Soalnya kan kalau bidang lain itu fokus ke satu lingkup aja, tapi kalau kita kan beda. Kita harus bisa menembus ke lingkup lainnya. Kita harus tahu semuanya dan itu butuh kita setiap hari belajar", ungkap Dinda (2017)

Pemaknaan yang serupa dengan keduanya juga diungkapkan oleh Dinda. Meski di perkuliahan tidak mempelajari jurnalistik sepenuhnya, pengalaman Dinda selama menjadi jurnalislah yang membentuk makna yang dimiliki oleh Dinda ini. Pengalaman Dinda melakukan berbagai liputan dengan isu serta lingkup ilmu yang berbeda-beda membuat Dinda memaknai profesi jurnalis sebagai profesi yang menambah ilmu. Dari berbagai liputan yang dilakukannya itu Dinda memiliki kesempatan untuk belajar mengenai hal-hal baru di setiap kesempatan yang ada. Because-motive Dinda adalah ketika dia melakukan berbagai liputan dan mempelajari halhal baru.

Sebagai perempuan yang bekerja sebagai jurnalis para informan penelitian ini juga memiliki pandangan terhadap perempuan jurnalis. Para informan memiliki makna positif terhadap perempuan jurnalis. Berdasarkan hasil penelitian, diketahui bahwa para informan 
Kajian Jurnalisme

ISSN 2549-0559 (cetak) ISSN 2549-1946 (online)

Volume 02 Nomor 01 Tahun 2018

memandang perempuan jurnalis sebagai sosok yang hebat, kuat, pintar, mandiri, dan pekerja keras. Para informan juga melihat bahwa perempuan jurnalis memiliki posisi yang setara dengan rekan jurnalis lainnya.

Dian, memandang perempuan jurnalis sebagai sosok yang hebat. Bagi Dian, perempuan jurnalis memiliki dua tanggung jawab berbeda, yaitu tanggung jawab pekerjaan dan tanggung jawab rumah. Mereka memandang para perempuan jurnalis sebagai sosok yang hebat karena dapat menjalankan serta membagi kedua tanggung jawab tersebut dengan baik.

"Kalau perempuan kan biasanya kerjaannya nggak cuma di tempat kerja tapi juga di rumah ngurus keluarga. Itu kan berarti mereka punya dua tuntutan yang berbeda.

Tuntutan pekerjaan sama tuntutan di keluarga", tutur Dian (2017)

Makna perempuan jurnalis sebagai perempuan yang kuat dimiliki oleh Liza, Revita, dan Dinda. Makna yang dimiliki ketiganya semakin kuat ketika mereka melakukan kerja jurnalistik di lapangan. Tuntutan perempuan jurnalis untuk bisa setara dengan rekan kerja laki-lakinya, serta dua tanggung jawab yang dimiliki perempuan, membuat keduanya memaknai perempuan jurnalis sebagai perempuan yang kuat.

"Kerenlah, bisa bagi waktu buat keluarga, waktu buat diri sendiri. Perempuan-perempuan yang jadi jurnalis di lapangan maupun yang di kantor itu kerenlah. Bisa sekuat itu. Kalau aku jadi dia belum tentu bisa sampai seperti itu. Belum tentu sekuat itu dan bisa terus sampai ke jenjang karir yang tinggi" tutur Liza (2017)

Dian juga memandang sosok perempuan jurnalis sebagai pekerja keras. Karena baginya pekerjaan sebagai jurnalis membutuhkan tenaga dan waktu yang cukup besar. Selain itu, dengan bekerja sebagai jurnalis, tentunya perempuan jurnalis tidak hanya diam seharian di dalam ruangan ketika melakukan pekerjaannya. Hal inilah yang membuat Dian memandang perempuan jurnalis sebagai pekerja keras.

Sementara Deasy, Revita, dan Dinda memandang sosok perempuan jurnalis sebagai sosok yang pintar. Bagi Deasy, Revita, dan Dinda, bekerja sebagai jurnalis membutuhkan pengetahuan yang banyak, wawasan yang luas serta kemauan untuk belajar. Hal tersebutlah yang membuat ketiganya melihat sosok perempuan jurnalis sebagai sosok yang pintar dengan wawasan yang luas.

Revita juga juga memaknai perempuan jurnalis sebagai perempuan yang mandiri. Profesi jurnalis yang menuntut perempuan jurnalis bepergian ke banyak tempat serta bertemu dengan banyak orang membuat dia memaknai perempuan jurnalis sebagai perempuan yang mandiri. Ini dijelaskan Schutz sebagai motif sebab.

Para informan, dalam konteks profesi jurnalis juga melihat, bahwa perempuan jurnalis dan laki-laki jurnalis memiliki kemampuan yang setara serta kesempatan yang sama. Meskipun, profesi jurnalis identik sebagai profesi maskulin yang pekerjanya didominasi oleh laki-laki.

Makna para informan tentang kesetaraan kesempatan dan kemampuan antara perempuan jurnalis dan laki-laki jurnalis ini didapat berdasarkan pengalaman mereka. Deasy misalnya. Berdasarkan pengalaman Deasy banyak atasannya di kantor yang merupakan perempuan. Hal inilah yang membuat Deasy memaknai bahwa antara perempuan dan laki-laki 
jurnalis itu memiliki kesempatan yang sama dalam hal jenjang karir. Ini dijelaskan sebagai because-motive atau motif sebab.

Sementara itu bagi Masayu kemampuan yang setara serta kesempatan yang sama ini dilihatnya berdasarkan pengalamannya di lapangan. Masayu sering kali diandalkan oleh rekan kerja laki-lakinya untuk melakukan kegiatan tertentu, seperti melakukan pendekatan kepada narasumber. Baginya hal itu menjadi salah satu bukti bahwa perempuan jurnalis juga dapat diandalkan untuk melaksanakan kerja-kerja jurnalis yang identik dengan laki-laki.

Hal yang sama juga diungkapkan oleh Liza. Liza memaknai posisi perempuan jurnalis ini berdasarkan pengalamannya di lapangan, di mana perempuan jurnalis sering kali diandalkan dan menerima tugas yang sama dengan laki-laki jurnalis.

"Karena sebenarnya di lapangan itu kadang ada yang lebih gampang kalau dicapainya sama reporter perempuan daripada reporter laki-laki. Ada yang lebih gampang kalau timnya perempuan semua atau timnya laki-laki semua. Sekarang banyak perempuan yang jago pegang kamera, jago VJ", tutur Liza (2017)

Pengakuan informan yang mengatakan bahwa ketika berada di lapangan, sering kali mereka diminta oleh teman-teman jurnalis laki-laki untuk melakukan pendekatan kepada narasumber, terlebih lagi jika narasumbernya laki-laki. Hal ini sebenarnya bisa dipandang dalam beberapa cara. Tindakan tersebut bisa dilihat sebagai salah satu wujud memaksimalkan potensi yang dimiliki oleh perempuan pekerja. Akan tetapi, bisa juga dipandang sebagai bentuk objektifikasi yang dilakukan terhadap perempuan pekerja.

Berdasarkan pengakuan informan tersebut, peneliti melihat bahwa tindakan tersebut menunjukkan bahwa para perempuan jurnalis ini mengalami objektifikasi oleh rekan kerjanya. Dibandingkan sebagai bentuk untuk memaksimalkan potensi yang dimiliki perempuan, tindakan tersebut lebih mengarah kepada penggunaan perempuan untuk mencapai tujuan para rekan kerja mereka, yakni melakukan pendekatan terhadap narasumber. Hal ini menandakan meskipun memiliki kemampuan yang sama, untuk hal-hal tertentu perempuan masih dijadikan sebagai objek.

Ditinjau berdasarkan Teori Patriarki dari Sylvia Walby, para perempuan jurnalis ini mengalami praktik patriarki. Praktik patriarki yang terjadi tersebut termasuk ke dalam struktur dasar patriarki ke enam, yakni budaya patriarki. Budaya patriarki merupakan struktur yang tercipta dari rangkaian beragam praktik-praktik patriarki dalam ranah filsafat, agama, pendidikan, maupun norma-norma tradisi. Pada budaya patriarki ini perempuan sering kali menjadi subjek yang direndahkan atau mendapat kerugian.

Sering kali para perempuan tidak menyadari bahwa mereka masih terjerat dalam praktik-praktik patriarki. Pada penelitian ini para informan tidak menyadari bahwa mereka terjebak dalam praktik budaya patriarki, yakni budaya di mana perempuan sering kali dimanfaatkan untuk melakukan pendekatan kepada lawan jenisnya. Para informan mengatakan bahwa ketika berada di lapangan, sering kali mereka diminta oleh teman-teman jurnalis lakilaki untuk melakukan pendekatan kepada narasumber, terlebih lagi jika narasumbernya lakilaki. Meskipun memiliki kemampuan yang sama, untuk hal-hal tertentu perempuan masih 
Kajian Jurnalisme

ISSN 2549-0559 (cetak) ISSN 2549-1946 (online)

Volume 02 Nomor 01 Tahun 2018

dijadikan sebagai objek. Hal ini menandakan bahwa praktik-praktik patriarki masih terus terjadi dan juga masih dilanggengkan.

Bagi para informan, perempuan jurnalis memiliki kemampuan serta kesempatan yang sama dengan rekan jurnalis lainnya, terutama rekan kerja laki-laki. Mereka juga mengatakan tidak melihat perbedaan yang cukup berarti dari segi kesempatan dalam hal jenjang karir. Bagi mereka hal tersebut kembali lagi kepada kemampuan dan kapabilitas yang dimiliki orang tersebut. Bahkan menurut mereka, tak jarang para perempuan jurnalis ini lebih diandalkan ketika harus berhadapan dengan situasi atau hal-hal tertentu. Makna tersebut dijelaskan Schutz sebagai because-motive yang dimiliki para informan, yakni masa lalu mereka sebagai jurnalis yang tidak menemukan perbedaan kemampuan dan kesempatan yang dimiliki dengan laki-laki jurnalis.

Berdasarkan hasil penelitian, dapat dikatakan bahwa interaksi antara perempuan jurnalis dengan orang-orang disekitarnya, yaitu rekan kerjalah yang membentuk pemaknaan para perempuan jurnalis. Because-motive atau faktor yang merujuk pada masa lalu informan juga membentuk bagaimana para perempuan jurnalis memaknai profesi jurnalis.

\section{Simpulan}

Berdasarkan hasil penelitian pemaknaan terhadap profesi jurnalis yang dimiliki para perempuan jurnalis televisi di Kota Bandung berasal dari masa lalu informan (because-motive), interaksi informan dengan orang lain, serta bagaimana orang lain memaknai hal yang sama. Makna profesi jurnalis bagi Perempuan jurnalis televisi di Kota Bandung di bagi menjadi tiga kategori, yakni (1) profesi yang menantang, (2) profesi yang membutuhkan keahlian, dan (3) profesi yang memperluas jaringan. Profesi yang menantang dimaknai sebagai profesi yang dinamis, penuh tantangan, dan menuntut tanggung jawab. Profesi yang membutuhkan keahlian dimaknai sebagai profesi yang membutuhkan passion atau keinginan yang tinggi, membutuhkan keberanian, dan membutuhkan idealisme. Profesi yang memperluas jaringan dimaknai sebagai profesi yang menambah relasi dan menambah ilmu. Bagi keenam informan, perempuan yang berprofesi sebagai jurnalis merupakan perempuan yang kuat, hebat, pintar, mandiri, dan pekerja keras. Perempuan jurnalis berkesempatan dan berkemampuan setara dengan laki-laki jurnalis.

\section{Daftar Pustaka}

Herawati, M. (2013). Women Media Producers in Indonesia: Promising Starter. International Conference on Communication and Culture in South East Asia Region, 19-31.

Herawati, M., \& Sutjipto, V. W. (2015). Female Journalist In The World and Indonesia: A Closer Look. Indonesia International Conference on Business, Management, and Communication (pp. 297307). Jakarta: Universitas Mercu Buana.

Herawati, M. (2016). Pemaknaan Gender Perempuan Pekerja Media di Jawa Barat. Jurnal Kajian Komunikasi Vol. 4 No. 1, 84-94.

Karlinah, S., dkk. (2012). Komunikasi Massa: Suatu Pengantar. Bandung: Simbiosa Rekatama.

Kattsoff, L. O. (1996). Pengantar Filsafat. Yogyakarta: Tiara Wacana Yogya. 
Kuswarno, E. (2009). Metode Penelitian Komunikasi Fenomenologi: Konsepsi, Pedoman, dan Contoh Penelitiannya. Bandung: Widya Padjadjaran.

Liza. (2017). Hasil Wawancara Dengan Reporter NET Jabar. Bandung

Luviana. (2012). Jejak Perempuan Jurnalis: Pemetaan Kondisi Kerja Perempuan Jurnalis di Indonesia. Jakarta: Aliansi Jurnalis Independen.

Masayu. (2017). Hasil Wawancara Dengan Reporter Kompas TV Jabar. Bandung

McQuail, D. (2011). Teori Komunikasi Massa, Edisi 6 Buku 1. Jakarta: Salemba Humanika.

Pate, A. C. (2014). Women In Journalism In The United Kingdom: An Analysis of Expectation and Experience of Equality Within The Profession 1970 To The Present. Inggris: University of The West of Scotland .

Revita. (2017). Hasil Wawancara Dengan Reporter CNN Indonesia Biro Jabar. Bandung

Sugiyono. (2012). Memahami Penelitian Kualitatif. Bandung: Alfabeta.

Sumadiria, A. H. (2005). Jurnalistik Indonesia: Menulis Berita dan Feature. Bandung: Simbiosa Rekatama.

Walby, S. (1991). Therizing Patriarchy. Cambridge: Basil Blackwell. 